\title{
Unveiling the Problems of Student Teachers during Practice Teaching in Nueva Ecija, Region III, Philippines
}

\section{LEILA M. COLLANTES ${ }^{1}$}

\begin{abstract}
Using purposive sampling, 386 student teachers were profiled and investigated on the problems they met during their deployment to 63 schools under four Teacher Education Institutions in Region III for the conduct of their practice teaching. Data were collected using a two-part survey questionnaire consisting of the student teachers' profile and problems they met then analysed through descriptive method using frequency, percentage, and rank. The study revealed that the problems encountered by student teachers include cooperating teachers do not hold regular class observations, noisy and talkative students, students' difficulty in expressing themselves in English, too much assignment given by school administrators and student teaching supervisor, uncooperative fellow student teachers, and lack of time and resources in preparing instructional materials
\end{abstract}

\section{Keywords}

Problems, student teachers, practice teaching/student teaching, Teacher Education Institutions (TEIs)

College of Sciences, Central Luzon State University, Science City of Muñoz, Philippines;

leilacollantes@,clsu.edu.ph 


\section{IRJE | Indonesian Research Journal in Education | | Vol. 5 | No. 1|June | Year 2021|}

\section{Introduction}

Teacher Education Institutions (TEIs) play a vital role in uplifting the quality of education in the Philippines. It is responsible in producing high caliber teachers who handle different subjects and mold the future leaders of Philippine society. To keep pace with the changes in society brought by technology and globalization, TEIs which consist of the Pre-service Education of Teachers (PET) and the In-Service Education of Teachers (INSET), collaborated by establishing a great partnership with the main stakeholders Commision on Higher Education (CHED), Professional Regulations Commission (PRC), Department of Education (DepEd), Civil Service Commission (CSC), towards the improvement of both pre-service and in-service training as another move to keep the teaching profession abreast with the changing demands of society. Student teaching is required for students who are not yet certified to teach. It lasts about the length of a semester, long enough to fulfill the college's assigned tasks. The student teaching program is designed to provide student teachers the opportunities to apply the principles and strategies of teaching and evaluation in actual teaching-learning situations, utilization of appropriate teaching techniques and instructional materials. During practice teaching, a pre-service teacher experiences the rudiments of teaching in a cyclical process of planning, actual teaching and evaluating learning. It is a college-supervised instructional experience, usually the culminating course in a university/college program leading to teacher education. For Cohen, Manion, and Morrison (1996 in Koross, 2010), student teaching in one form or another has remained an unchallenged, essential element in the preparation of generations of teachers since the establishment of TEIs in the middle and late $19^{\text {th }}$ century.

Ganal, Andaya, and Guiab (2016) underscored the known fact that student teachers lack the skills and capability to effectively and efficiently perform the role of a teacher. Student teachers are prompted with the problems and difficulties in terms of instruction, classroom management, evaluation, school, learners, teachers and other stakeholders among others. Laruan (2006) enumerated the problems and difficulties encountered by the student teachers. These include problems on personal and emotional aspects, teachers' preparation, class participation, class management, instruction, evaluation, learners, workload, and guidance. For Manion, Keith Morrison and Cohen (2003), student teaching creates a mixture of anticipation, anxiety, and apprehension among student teachers as they begin their teaching practice. Though there are studies that focused on the problems encountered by student teachers, there is a need to further explore on these problems and validate if those problems still exist in the present context. Likewise, previous studies conducted were from the perspective of cooperating teachers and academicians, none so far were from the perspective of student teachers themselves. Hence the present study investigated the profile and analyzed the problems encounter by the student teachers from 63 cooperating schools of the four TEIs in Region 3. 


\section{IRJE | Indonesian Research Journal in Education | | Vol. 5 | No. 1|June | Year 2021|}

\section{Literature Review/Theoretical Frameworks}

The preparation of pre-service teachers requires sincerity and steady effort on the part of teacher educators. The task is made daunting by the fact that the need for new teachers is great - greater than the number of teachers' education colleges can produce (Soslau \& Raths, 2017). According to Okubia, Augustine, and Osagie (2013) teaching practice is a vital aspect of teacher preparatory program in teacher training institutions. It serves as an opportunity for student-teachers to be exposed to the realities of teaching and professional activities in the field of education. For Henry (1989), student teaching is one of the most important aspects of any pre-service program, if not the main event. According to Perry (2004), student teaching is also time for excitement and challenges.

According to Haigh, Pinder, and McDonald (2006) practice teaching in educations is still a challenge since it does not fully prepare student teachers for the actual classroom teaching. Samson et al. (2007) revealed in their study that the problems and difficulties encountered by the student teachers were related to teacher's preparation, class participation, class management, instructional, emotional, adjustment to students and school and over-extended schedules or workload. The importance of identifying the problems met by the student teachers has been explored in the literature. In fact, numerous studies were conducted about the problems met by the student teachers which include the studies of Ganal (2016), Koross (2016), Okubia et al. (2013), Prastomu and Listyani (2016), Samson et al. (2007), Saricoban (2013), Soslau and Raths (2017), Tok (2010), and Ula (2016). The gap is widened by the fact that almost half of the teachers recruited into the profession leave after only five years of practice. The second thread is the general dissatisfaction found in the public and the profession itself with respect to the requirements and the outputs of teacher education programs. Many critics see the process as unneeded, soft in its implementation, and weak in its conception of the needs of beginning teachers. Wrigth (1988) cited in Saricoban (2010) mentioned that in the classroom, teaching and learning can be considered as social activities that involve relationships between not only the teacher and students, but also between these parties (teacher-students) and materials, equipment classroom, thus student teachers have to adapt themselves to the new environment. Cooperating schools are committed partners of TEIs in making and producing student teachers to become excellent, dedicated and highly spirited educators, imbued with enough knowledge, wisdom, skills, and attitudes to face the dramatic and relentless world of teaching. The cooperating teachers are wise, trusted and significant persons who play vital roles to student teachers in differing degrees for a different length of time. As experienced teachers themselves, sharing their experiences with student teachers would likely inspire them to meet the challenges that await them in the world of real teaching. These statements from education authorities stress the importance of experiences student teacher will gain during their student teaching, which could serve as strong determinants for their love for the profession. 


\section{IRJE | Indonesian Research Journal in Education | | Vol. 5 | No. 1|June | Year 2021|}

\section{Methods}

\section{Research design, site, and participants}

This study particularly utilized the survey research in gathering the problems encountered by the student teachers from different TEIs deployed in different cooperating schools in Nueva Ecija. Adanza (1995) defined survey as method with the intent to gather a relatively limited data from a relatively large number of subjects. It serves the purpose of describing current or prevailing conditions, opinions, attitudes, impressions, perceptions of a group of people, or description of objects. It is essentially getting data or information from a variety of subjects. It was used to measure existing phenomenon without inquiring why it exists. In this study, it was used to determine the problems encountered by the student teachers during the conduct of their practice teaching. Data were gathered from 63 cooperating schools under the four different TEIs in Nueva Ecija, two of which are state universities (Nueva Ecija University of Science and Technology (NEUST), Cabanatuan City; and the Central Luzon State University (CLSU), Science City of Munoz; and two are private institutions (Wesleyan University-Philippines and the Araullo University, both located in Cabanatuan City.

The respondents were composed of student teachers from selected public and private TEIs in Nueva Ecija. The 383 student teachers who participated in the study were deployed to 63 cooperating schools. Majority of the respondents were single females; in their early adulthood stage in life; Tagalogs with both parents having attained secondary education as their highest educational attainment and had average fair grades in all their subjects prior to practice teaching. Purposive sampling was used in this study. Martinez (1994) emphasized purposive sample as a deliberate sampling technique where the researchers select a particular group or groups based on certain criteria or purposes or variables. It is a sample selected by a researcher which in his judgment is a representative sample. This sampling technique was utilized to realize the purpose of investigating the problems encountered by the student teachers during the conduct of their practice teaching.

\section{Data collection and analysis}

The instrument used for the study consisted of two parts and were answered as follows. Part I dealt with the profile of the student respondents and was answered by supplying the needed information on the different items under profile variables. Part II items dealt with the problems met by student teachers. Some pre-surveyed problems were enumerated, and the participants were asked to check as many items as applicable. They were also given the opportunity to add some problems which had not been included in the list. The different responses were counted and ranked according to their frequency. The content validity of the questionnaire was determined through consultations with experts who were knowledgeable on the topic and scope of the study. All their suggestions for the improvement of questionnaire were incorporated in the final copy. To establish the reliability of the questionnaire, pilot-testing was done in one of the TEIs in Nueva Ecija. The Test-retest method gave a value 


\section{IRJE | Indonesian Research Journal in Education | | Vol. 5 | No. 1|June | Year 2021|}

of 0.81 , which indicated that the instrument was reliable. The researcher did a pre-survey prior to the conduct of the study. During the pre-survey, the researcher sought the permission of the Deans of the different TEIs. In treating the data on profile variables, frequency and percentage were used. On the problems encountered by the student teachers during the conduct of student teaching program as well as their recommendations to solve such problems, frequency, percentage, and rank were utilized.

\section{Findings}

This section presents the findings of the study. It begins with the problems they met with their cooperating teachers and students. These were followed by the personal problems encountered, problems met with the administrators, principals and department heads, and problems met with their fellow student teachers. The last part presents the problems met by the student teachers in preparing the instructional materials and their cooperating teachers. Tables 1-7 present the problems met by the student teachers with their cooperating teachers, students being handled, administrators or principal and area chairs, fellow student teachers, instructional materials production and student teaching supervisor.

\section{Problems of student teachers with their cooperating teachers}

Table 1 shows the problems of student teachers with their cooperating teachers. Ranked one with 48 or 14.59 percent indicated that greatest problem was their concern over cooperating teacher "who do not hold regular class observations".

Table 1. Problems met by the student teachers with their cooperating teachers

\begin{tabular}{|c|c|c|c|}
\hline Problems & & & \\
\hline Cooperating teacher & f & $\%$ & Rank \\
\hline $\begin{array}{l}\text { 1. Cooperating teachers do not hold regular class } \\
\text { observations. }\end{array}$ & 48 & 14.59 & 1 \\
\hline $\begin{array}{l}\text { 2. Inability of cooperating teachers to give clearer } \\
\text { instructions and directions in teaching strategies. }\end{array}$ & 41 & 12.46 & 2 \\
\hline $\begin{array}{l}\text { 3. Cooperating teachers } \\
\text { do not accept use of varied teaching methods. }\end{array}$ & 5 & 1.52 & 7 \\
\hline $\begin{array}{l}\text { 4. Cooperating teachers do not hold post conference } \\
\text { / feedback as often as possible. }\end{array}$ & 36 & 10.94 & 4 \\
\hline $\begin{array}{l}\text { 5. Cooperating teachers do not offer suggestions } \\
\text { towards the betterment of teaching-learning process. }\end{array}$ & 23 & 6.99 & 5 \\
\hline 6. Cooperating teacher is often absent. & 3 & 0.91 & 8 \\
\hline 7. Cooperating teacher is often late. & 17 & 5.17 & 6 \\
\hline 8. Poor relationship with cooperating teacher. & 38 & 11.55 & 3 \\
\hline
\end{tabular}

Ranked second in the problems met by student teachers with their cooperating teachers was on the "inability of cooperating teachers to give clearer instructions and directions in teaching methodologies/strategies" with 41 or12. 46\%. This problem was 


\section{IRJE | Indonesian Research Journal in Education | | Vol. 5 | No. 1|June | Year 2021|}

followed by poor relationship with cooperating teachers as problems in the third rank with 38 or $11.55 \%$; and the fourth problem with 36 or $10.94 \%$ was about the lack of post-conference or feedback by the cooperating teachers. The other problems identified were none acceptance of the cooperating teachers on the use of new strategies being introduced by student teachers, and on the attendance and punctuality of the cooperating teachers.

\section{Problems of student teachers with their students}

Table 2 shows the problems of student teachers with their students. Topping the list or ranked one with 298 or $90.58 \%$ was on the noisiness and talkativeness of the students, followed by the absenteeism of their students with 155 or $47.11 \%$. The tardiness of their students was the third outstanding problem of the student teachers with 136 or $41.34 \%$. The fourth problem identified by the student teachers was students who were disrespectful with 121 or $36.78 \%$. The other problems met by the student teachers who ranked fifth, sixth, and seventh were the following: slow learner students (111 or 33.74\%), students not participating in the class (95 or $28.88 \%$ ) and students who tried courting their student teachers (25 or $7.60 \%$ ).

Table 2. Problems met by the student teachers with students

\begin{tabular}{llccc}
\hline Problems & & & \\
\cline { 1 - 1 } Students & Total & & Rank \\
\hline 1. & Tardiness of students/pupils. & 136 & 41.34 & 3 \\
2. Absenteeism of students/pupils. & 155 & 47.11 & 2 \\
3. Noisy and talkative students/pupils. & 298 & 90.58 & 1 \\
4. Students do not actively participate in class & 95 & 28.88 & 6 \\
discussions & 121 & 36.78 & 4 \\
5. Disrespectful students & 25 & 7.60 & 7 \\
6. Students who try to court their student teachers & 111 & 33.74 & 5 \\
7. Students are slow learners & &
\end{tabular}

\section{Personal problems met by the student teachers}

Table 3 shows the ranking of the personal problems encountered by the student teachers. The first problem of the student teachers which they considered personal was their difficulty in expressing themselves in the English language with 124 or 37.69\%. This was followed by the difficulty of instilling discipline among students when the cooperating teacher was not around with 118 or $35.85 \%$. Other personal problem was their lack of money in preparing instructional materials with 102 or $31 \%$. The last two problems which were identified ranked four and five respectively was their lack of confidence to face an audience ( 27 or $8.21 \%$ ) and inadequate learning foundation on basic education principles (20 or $6.08 \%$ ). 


\section{IRJE | Indonesian Research Journal in Education |}

| Vol. 5 | No. 1|June | Year 2021|

Table 3 Personal problems met by the student teachers

\begin{tabular}{lccc}
\hline Problems & Total & \% & Rank \\
\hline Personal & 20 & 6.08 & 5 \\
\hline $\begin{array}{l}\text { Inadequate learning foundation on basic } \\
\text { education principles. }\end{array}$ & 124 & 37.69 & 1 \\
$\begin{array}{l}\text { Difficulty in expressing oneself in the } \\
\begin{array}{l}\text { English language. } \\
\text { Difficulty in instilling discipline among } \\
\text { student when the cooperating } \\
\text { teacher/mentor is not around. }\end{array}\end{array}$ & 118 & 35.87 & 2 \\
$\begin{array}{l}\text { 4ack of confidence to face an audience. } \\
\text { 5. Lacks money for preparation of } \\
\text { instructional materials. }\end{array}$ & 27 & 8.21 & 4 \\
\hline
\end{tabular}

\section{Problems met by the student teachers with administrators/principals/chairs of cooperating schools}

Table 4 shows that the greatest problem with the school administrators had to do with "too many requirements given by the principals/chairperson" which is ranked one with 33 or $10.03 \%$. Ranked second (27 or $8.21 \%$ ) in the list of problems was on the strictness of the administrators. Another problem encountered by the student teachers had to do with the strictness of the principals/chairpersons specifically the unapproachable style of the former which was also interpreted by the student teachers that they were not welcome in the department (19 or $5.78 \%$ ). And the last problem they mentioned was the donations asked by the principals/chairpersons at the end of the student teaching with 4 or $1.22 \%$.

Table 4. Problems met by student teachers with administrators/principal/ chairs of cooperating schools

\begin{tabular}{|c|c|c|c|}
\hline Problems & & & \\
\hline Adm/principal/chair & Total & $\%$ & Rank \\
\hline $\begin{array}{l}\text { 1. Administrators give a lot of } \\
\text { requirements. }\end{array}$ & 33 & 10.03 & 1 \\
\hline 2. Administrators are very strict. & 27 & 8.21 & 2 \\
\hline 3. Unapproachable administrators & 19 & 5.78 & 3 \\
\hline $\begin{array}{l}\text { 4. Administrators who do not give them } \\
\text { feeling of belongingness. }\end{array}$ & 14 & 4.26 & 4 \\
\hline $\begin{array}{l}\text { 5. Administrators asking for too much } \\
\text { donations. }\end{array}$ & 4 & 1.22 & 5 \\
\hline
\end{tabular}




\section{IRJE | Indonesian Research Journal in Education | | Vol. 5 | No. 1|June | Year 2021|}

\section{Problems met by the student teachers with their fellow student teachers}

Table 5 shows the problems met by student teachers with their fellow student teachers. Ranked first with 31 or $9.42 \%$ was the lack of cooperation from their fellow student teachers. Adjustment problems with their fellow student teachers ranked second with 19 or $5.78 \%$. The third with 18 or 5.47 on the list of the problems had to do with "Fellow student teachers who do not like to share their ideas or to extend help to co-teachers".

Table 5. Problems met by the student teachers with fellow student teachers

\begin{tabular}{|c|c|c|c|}
\hline Problems & & & \\
\hline Fellow Students & Total & $\%$ & Rank \\
\hline 1. Unfriendly fellow student teachers & 15 & 4.56 & 4 \\
\hline $\begin{array}{l}\text { 2. Student teachers using things } \\
\text { without permission from fellow } \\
\text { student teacher. }\end{array}$ & 9 & 2.74 & 6 \\
\hline $\begin{array}{l}\text { 3. Adjustment problems with fellow } \\
\text { student teachers }\end{array}$ & 19 & 5.78 & 2 \\
\hline $\begin{array}{l}\text { 4. Uncooperative fellow student } \\
\text { teachers }\end{array}$ & 31 & 9.42 & 1 \\
\hline $\begin{array}{l}\text { 5. Fellow student teachers who tell a } \\
\text { lot of story which are not true. }\end{array}$ & 11 & 3.34 & 5 \\
\hline $\begin{array}{l}\text { 6. Fellow student teachers who do not } \\
\text { like to share their ideas or extend } \\
\text { help to colleagues }\end{array}$ & 18 & 5.47 & 3 \\
\hline
\end{tabular}

Problems met by student teachers regarding preparation of instructional materials

Table 6 shows the problems encountered by student teachers regarding preparation of instructional materials. Their first problem had to do with the lack of time in preparation of instructional materials (122 or $37.08 \%$ ). The next problem dealt with the use of instructional materials (i.e., LCD, laptop computers, desktop) which could not be applied to their student because their cooperating schools lacked the facilities and equipment needed with 105 or $31.91 \%$. This was followed by the lack of money to afford these teaching materials with 95 or $28.88 \%$. Too many teaching devices needed for lesson ranked $4^{\text {th }}$ with 67 or $20.36 \%$. Lack enough skill in preparing and using teaching devices with 32 or $9.73 \%$ and 16 or $4.86 \%$, respectively. 
Table 6. Problems met by the student teachers regarding preparation of instructional materials

\begin{tabular}{|c|c|c|c|}
\hline \multicolumn{4}{|l|}{ Problems } \\
\hline Instructional Materials & Total & $\%$ & Rank \\
\hline $\begin{array}{l}\text { 1. Too many teaching devices needed for the } \\
\text { lesson. }\end{array}$ & 67 & 20.36 & 4 \\
\hline $\begin{array}{l}\text { 2. Not having much time for preparation of } \\
\text { instructional materials. }\end{array}$ & 122 & 37.08 & 1 \\
\hline $\begin{array}{l}\text { 3. Not enough money to purchase materials for } \\
\text { use as teaching devices. }\end{array}$ & 95 & 28.88 & 3 \\
\hline $\begin{array}{l}\text { 4. Lacks enough skill in preparing teaching } \\
\text { devices }\end{array}$ & 32 & 9.73 & 6 \\
\hline 5. Lacks skill in using prepared teaching devices & 16 & 4.86 & 7 \\
\hline $\begin{array}{l}\text { 6. Teaching devices learned in the university } \\
\text { cannot be applied because of limited } \\
\text { equipment in the school like LCD projector }\end{array}$ & 105 & 31.91 & 2 \\
\hline $\begin{array}{l}\text { 7. No available alternative teaching device in the } \\
\text { community }\end{array}$ & 39 & 11.85 & 5 \\
\hline
\end{tabular}

\section{Problems met by student teachers with their student teaching supervisors}

Table 7 shows the problems of student teachers with their student teaching supervisors. Based on the data from Table 7, their first problem was having too many requirements to accomplish such as action research, narrative reports, case study and journal in their everyday teaching experiences with 39 or $111.87 \%$. Student teachers also found too many deadlines a problem with 31 or $9.42 \%$. Next was inconsistent instructions given by their supervisors $(25$ or $7.60 \%$ ). Finally, student teachers find the meetings called by the supervisors time consuming with 13 or $3.95 \%$. For them, the time spent attending in these meetings could have been devoted to preparing their instructional materials.

Table 7. Problems met by student teachers with their student teaching supervisor

\begin{tabular}{llcc}
\hline Student Teaching Supervisor & Total & $\mathbf{\%}$ & Rank \\
\hline 1. Too many requirements to & 39 & 11.85 & 1 \\
accomplish & 13 & 3.95 & 4 \\
2. Keep on calling for a meeting & & & \\
$\quad \begin{array}{l}\text { which disrupts concentration in } \\
\text { teaching }\end{array}$ & 31 & 9.42 & 3 \\
3. Too many deadlines to meet & 25 & 7.60 & \\
4. Inconsistencies in giving & & & \\
instructions which confuse \\
student teachers/mentees
\end{tabular}




\section{IRJE | Indonesian Research Journal in Education | | Vol. 5 | No. 1|June | Year 2021|}

\section{Discussion}

Tok (2010) posited that practice teaching is a period of helping the student teachers to try out and make more meaningful use of the principles they learned while in the college or university. With the help of cooperating teachers, it is designed to provide opportunities and guidance in a school setting for student teachers to develop themselves. For Ambrosettie (2014), practice teaching is a collaborative journey between the cooperating teacher and the student teacher, a good guidance and monitoring from the mentor teachers should be well-considered in order to better prepare the student-teachers become qualified teachers in the future. According to Prastomo and Listyani (2016), a cooperating teacher ideally helps student- teachers in their student teaching. A cooperating teacher is expected to give adequate feedback for student teachers about their teaching. However, this seems not properly observed as revealed in the findings given that the real root of the problems of the student teachers with their cooperating teachers was the irregular class observations performed by the latter. As a result, cooperating teachers could not hold regular post conference/feedback because they would not be able to give reliable feedbacks based on actual observations, and yet they begrudged their student teachers if the latter did not perform well. This situation resulted inevitably to student teachers' lack of faith and trust to their cooperating teachers. They opted not to consult them anymore given the notion that their cooperating teachers would not know whether their student teachers implemented their suggestions or not due to their physical absence from the classroom. Student teachers contended that without the rigid supervision of their cooperating teacher, they would not be able to determine whether they did the right thing in their methodology. This conforms to the study conducted by Gokce and Demirhan (2005) where cooperating teachers did not sufficiently support student teachers in the process of developing lesson plans. In the study of Baslurk (2009) the same findings was revealed about pre-service teachers who did not do talking with their mentors about their lesson plans before teaching. Likewise, the presence of cooperating teachers during class sessions enabled them to be more effective teachers because students give their attention/respect to them. Otherwise, classes are reverted to a noisy congregation in the absence of their real teacher who gives them grades.

The center of any educative process is the student. Without the student there would be no need for teaching. It is the task of the teacher to guide the students in the learning processes. But each student is a unique individual who respond differently; hence, along the teaching and learning process and in guiding the students, problems might arise. The problems of student teachers with their students were on the noisiness and talkativeness of the students. This could be strongly related with the earlier problem of student teachers with their cooperating teachers as regards the non-observance of regular class observations. Cooperating teachers play an active role in disciplining students. Students chat with their seatmates and do not pay attention because of several reasons. First, they are not afraid or threatened with the presence of student teachers. Second, they do not take seriously their student teachers because of the perception that they are not their real teachers and that they are just there to practice their profession. Third, it is their way of getting attention to be recognized and pinpointed in the class. These are the so-called "KSP" students, or "Kulang 


\section{IRJE | Indonesian Research Journal in Education | | Vol. 5 | No. 1|June | Year 2021|}

Sa Pansin" (attention seeker) who intentionally create noise to catch student teachers' attention. Another source of this problem with students was probably the failure of the student teachers to properly motivate students and raise students' curiosity, and this situation could be due to their lack of experience on handling energetic students. According to Havighurst (1953), students who belong to ages 7-16 are generally active and attention seekers, thus it was not surprising if student teachers met such problem. The second problem met by the student teachers was on students' absenteeism. This again can be related to student teachers' problem with their cooperating teachers, who did not regularly hold class observations. Cooperating teachers were supposed to serve as models to their student. As such, when students learned that their real teacher (i.e., cooperating teacher) was not coming to class regularly to oversee them, then they felt free to do what they wanted. They were not afraid to be marked absent because of their belief that it would not affect their final grades or that the grades given by the practice teacher will not have much weight on their marks. Other students lose interest since majority of the class were noisy and unruly, so they preferred to be somewhere else, than in the classroom. The tardiness of their students was also identified as problems of the student teachers. Students were not afraid to be reprimanded by their student teachers. Student teachers themselves admitted that they were naturally soft-spoken and were always reminded not to impose too strict discipline to avoid complaints from parents. As a teacher herself, the researcher has not been exempted from their problem especially nowadays. Even college students almost always commit tardiness, which seems to be irritating to teachers since late comers distract the attention of the class from listening to her lecture. Likewise, latecomers are deprived of catching up with the lesson. As early as in the grade school, there is a felt need for students to be taught punctuality. The fourth problem identified by the student teachers was students who were disrespectful. This is similar to what Prastomo and Listyani (2016) surmised that student-teachers have to deal with various kinds of students' behavior. According to student teachers, handling teenage schools' students is not as easy as people think. They sometimes suddenly become frozen or nervous when they come to the real classroom with real students. Students only give their respect to student teachers who excel academically or to those who are smart. They even test the intelligence and capability of the student teachers, and if the latter passed their acid test or challenge only then would they vow, recognize, respect, and obey their student teachers. So, student teachers need to struggle to earn respect and admiration from their students. It would only be possible if they had acquired mastery of the subject matter and were presentable in their physical looks. As emphasized in the preamble of Code of Ethics of Professional Teachers, "teachers should possess dignity and reputation with high moral values as well as technical and professional competence." The problems mentioned above were similar to the findings of Tok (2010), that the most important problems that student teachers experience are "motivating students, communicating with students and managing students". The reason for this may be that student teachers are not viewed as real teachers by learner. It also conforms to the findings of Saricoban (2010) that student teachers reported that their students lack interest in learning.

The first problem of the student teachers, which they considered personal, was their difficulty in expressing themselves in the English language, which is also the first thing 


\section{IRJE | Indonesian Research Journal in Education | | Vol. 5 | No. 1|June | Year 2021|}

noticed by their respective cooperating teachers. Student teachers had strong desire to share all their ideas skills, or language barrier; it prevented them from bringing out new and brilliant ideas. Also, this problem on communication was one because of their shyness. Afraid of committing errors in English, student teachers admitted they just kept quiet. Similarly, in 2013, Rakasiwi found out that there were some student teachers who thought that their ability to teach English was insufficient. Poor communication results in failure on the part of the pupils and feedback the student teachers receives for poor communication is very poor responses from his pupils. When this occurs, the pupils suffer a grave handicap because they become helpless in the face of unclear and complex messages. The price the student teacher pays for poor communication is exertion of more energy to make the pupils respond accurately to his messages (Olaitan \& Agusiobo, 1981). The foregoing results strengthen the fact that the task of a teacher is multifaceted and demands variety of human traits, abilities, and competencies. It is a task that calls for an assessment of one's own personal qualifications. In the genuine desire of student teachers to improve on them it becomes a source of their problem. The next problem they mentioned was difficulty of instilling discipline among students when the cooperating teacher was not around. Cooperating teachers play a vital role in practice teaching. They are second parents to students. They really develop the moral character of their students. As cooperating teachers, they were expected to help student teachers build camaraderie with the students. They should make it sure that student teachers had already established good rapport with students before finally leaving the student teacher all alone in the classroom. Cooperating teachers were also recognized as authority figure in the classroom and so their presence or absence had a great impact on the behavior of the students. This was recognized by student teachers whenever they would leave the class to them alone. Another problem considered personal by the student teachers was their lack of money in preparing instructional materials. As shown in their profile, majority of them came from poor families and almost all of them were enrolled in public universities due to financial constraint, so they only had exact allowance for their basic school needs. Although they were willing to provide best instructional materials to make teaching and learning effective and efficient, financial difficulty prevented them from doing it. The last problem they identified was their lack of confidence to face an audience and inadequate learning foundation on basic education principles. This is just a natural tendency since they were considered novice teacher in the world of teaching. Their short exposure and little experience were not enough to give them confidence. Their self-making process is not yet finished, since gaining enough confidence is almost a life time. And another contributory factor in not having enough preparation was their lack of mastery of the lesson.

The School Principal serves as the leader of an entire community within a school for he or she ensures that the organization runs smoothly as well as the facilities and staff. He or she is responsible for managing the major administrative tasks and supervising all students and teachers. Even though student teachers did not have everyday contact with the administrators/principals and chairpersons of the department where they belonged, they still had few problems with them. Student teachers had several duties and obligations they needed to accomplish in the classroom such as: preparing lesson plans, teaching, checking test papers, recording results of test, and preparing visual materials. Their long and arduous 


\section{IRJE | Indonesian Research Journal in Education | | Vol. 5 | No. 1|June | Year 2021|}

period of preparation for those activities mentioned above exhausted their energy. This was understandable in the light of their adjustment period as well as total and full immersion in the actual world of teaching. So as much as they would like to accomplish the activities assigned to them by their chairperson like, serving as substitute whenever a teacher was on leave, requesting them to label the different books in the department, and putting designs on the bulletin boards of the department where they belonged, became sources of their problems. Ranked second in the list of problems was on the strictness of the administrators. As a leader, administrators took this stance of being strict in their desire of maintaining order and discipline in their area of jurisdiction, but student teachers distanced themselves from school leaders because they knew they were being assessed, hence their personal distance became even wider. As the interviews revealed, their chairperson required them to avoid too much familiarity with students, since "familiarity brings contempt", and this even extended to school administrators. The shift from being college students to becoming real teachers gave them difficult time since they have not been familiar yet with the ways of superiors to subordinates. Student teachers themselves also admitted that they were sensitive, easily discouraged and lacked emotional maturity, and these feelings contributed to their being intimidated by their chairperson(s). The third problem encountered by the student teachers associated with the strictness of the principals/chairpersons was the unapproachable style of the former which was also interpreted by the student teachers that they did not belong to the department. This was related to the findings of Koross, (2016) where student teachers stated that some school rejected student teachers. And the last problem they mentioned was the donations asked by the principals/chairpersons upon leaving the school. Student teachers came from poor families; they went through with several expenses in their practice teaching program and were facing many more expenses for their forthcoming graduation, and so donation for them became also a problem.

According to an interview, student teachers were sent to their cooperating schools together with their fellow student teachers who came from different sections and with different major fields of specialization. Their student teaching supervisors usually assigned a team leader and an assistant team leader in a respective cooperating school to facilitate in the monitoring and communication of one another. But during group meetings, some did not like to participate resulting to lack of consensus when decisions were reached. This same group of student teachers was the first to object or to question when a decision was being implemented resulting to misunderstandings between groups and/or individuals. Interpersonal relationships became strained. Adjustment problems with their fellow student teachers were the effects of student teachers' individual differences, different perceptions, different beliefs, and different experiences. Some adjustment problems also stemmed out of students' behaviors and attitudes. While some assumed superiority, others showed inferiority but also refused to be sidelined. These functions in relationships were inevitable in close interactions among young people who were still unable to fully understand themselves. "Fellow student teachers who do not like to share their ideas or to extend help to co-teachers" ranked as the $3^{\text {rd }}$ problem of the student teachers with their fellow student teachers. This situation was actually a result of individuals who were forced by circumstances to be part of one community with one common goal to achieve. Considering that was the first time they met, it was expected that they be reserved in dealing with others who 


\section{IRJE | Indonesian Research Journal in Education | | Vol. 5 | No. 1|June | Year 2021|}

belonged to another group. Filipino culture played a big part in this problem. Extending unsolicited assistance, advice, and being too familiar immediately after their first few meetings tended to turn off other people. However, these actuations were interpreted differently by young people. Student teaching supervisors need to give proper orientation to student teachers along this aspect to make student teaching experiences more meaningful to them.

Instructional materials/media are integral components of almost all teaching strategies. They are often referred to as "sub strategies" since their role is as important as the preferred methodology to be employed. They never failed to arouse students' curiosity in sustaining their interests especially when a new topic is being introduced. They serve as stimuli which can result to a lively classroom interaction. According to Olaitan and Agusiobo as cited by Tok, (2016) leaning and teaching can be improved by effective selection and use of instructional materials because they appeal to human senses. Lessons delivered with the use of suitable teaching aid motivate pupils to learn and remember what is learnt when there is a recall. When instructional materials are efficiently utilized by a student teacher, they help to stimulate the interest of the pupils, reduce number of verbal responses, make learning more permanent, and provide experiences not easily secured in other ways. When effectively used, they offer a reality of experience which stimulates individual activity and motivates pupils to investigate or explore, theyr increasing voluntary reding in pupils. But despite its importance, student teachers identified it as one source of their problems. This concurs with Okoli and Meziorle's (2011 in Okubia et al., 2013) findings that the lack of necessary equipment and materials is one of the problems faced by student teacher. Student teachers faced very hectic schedules due to the different teaching assignments and extra assignments given by their respective cooperating teachers. Because of their different tasks they found little time in preparing for their instructional materials. The teaching devices they learned in the university which could not be applied to their practice teaching days because their cooperating schools lacked the facilities and equipment needed, like LCDs and computers. So as much as they wanted to apply the different modern instructional materials/tools they could not do it because of limited resources. Thus, they resorted to the use of traditional instructional materials using pentel pens and Manila paper, the preparations of which were very tedious and time-consuming. This is parallel to the findings of Koross (2016) wherein students mentioned that some schools lack instructional materials that are needed for effective teaching. Not having enough money was the third problem encountered by the practice teachers. Materials used in preparing visual aids were expensive. As mentioned earlier, majority of the students came from poor families so they could not afford to buy expensive materials because their allowances were barely enough for their meals and fare expenses every day. Student teachers revealed in interviews that these financial problems worsen their worries and anxieties. This was also identical to the findings of Koross (2016) where the student teachers indicated that they face financial challenges during teaching practice and that majority of them stated that they lacked finances for their upkeep.

Student teaching supervisors oversee the various activities of student teachers. They provide support for the student teachers and cooperating teachers, clarify requirements and assist them in organizing, planning, reviewing teaching and scheduling class. As early as 1990, Guyton and McIntyre found that student teachers' supervisors may be the cause of the 


\section{IRJE | Indonesian Research Journal in Education | | Vol. 5 | No. 1|June | Year 2021|}

problems since they are not specialist, nor are they adequately trained to provide field instructions across several content areas and not to mention in the areas of supervision. As such, they may not have the proper training in terms of guiding the would-be teachers. Based on the data, giving too many requirements to accomplish such as action research, narrative reports, case study and journal regarding their day to day teaching experiences becomes one of the sources of their problems. Inconsistent giving of instructions was found by student teachers a source of their problem since they meant business. They wanted their student teaching supervisors to be consistent in. Berchuke et al (2013) further revealed in their study that university assessors are not consistent in their duties as supervisors. Lastly attending meetings and/or general assemblies with faculty, called by their student teaching supervisors, consumed much of their time, which could otherwise be devoted to completion of other requirements. They felt, anyway, that their opinions did not matter so the idea of attending such meetings seems irrelevant for them. On this regard, student teachers need to be reminded that meetings are part of life of a real teacher; hence there is a need for them to learn how to manage time effectively.

\section{Conclusion}

As the adage goes, "No man is an island". For student teachers to achieve his goal of becoming an effective and efficient teacher, he needs to hurdle the rigors of student teaching. During student teaching program, meeting significant people will play different roles to fully attain his/her holistic development and be prepared and competitive for the world of work. As part of his immersion, interactions to different people in the cooperating school are imperative and inevitable. These significant people are agents of change, channels of improvement and building blocks for them to transform from being novice to full-pledged professional teachers. They can also be likened to a coin; one side of it represents motivation and inspiration while the other side of it can be frustration and problems. The study revealed that the problems encountered by student teachers include cooperating teachers do not hold regular class observations; noisy and talkative students; students' difficulty in expressing themselves in English; too much assignment given by school administrators and student teaching supervisor; uncooperative fellow student teachers; and lack of time and resources in preparing instructional materials. From these results, it can be concluded that the common problems that surfaced during the practice teaching of student teachers arise from the different sources such as: cooperating teachers, students, fellow student teachers, supervisors, principals/head, personal and instructional materials. For each of the said sources, student teachers identified the greatest and the least problem. The study revealed that all these sources contribute to the problems met by the student teachers.

Since the present study endeavored on the problems met by student teachers from the various individuals they encountered during the program, the findings offer a significant and peculiar contribution to the literature in education in general, and in student teaching in particular. Exploring the problems encountered by cooperating teachers may lead to awareness among administrators, professional education professors, student teaching 


\section{IRJE | Indonesian Research Journal in Education | | Vol. 5 | No. 1|June | Year 2021|}

supervisors, cooperating teachers and student teachers themselves on the kind of problems encountered by the latter while they are immersed in the program.

In light of the foregoing results, TEIs may conduct orientation for cooperating teachers as regards their roles and responsibilities to the student teachers. Regular class observation to track down the strengths, weaknesses and improvement of the student teachers so that they can improve themselves on the process of doing student teaching may also be done. Cooperating teachers and supervisors may maintain open communication to address the needs and problems of student teachers in all aspects of the profession during practice teaching. Cooperating teachers may help the student teachers establish camaraderie with the students so as to help them implement the plans made and gain a memorable and enjoyable experiences from their practice teaching. Equipped the student teachers with knowledge and skills in dealing with the students effectively by providing a curriculum would enhance their social ability to interact with their students effectively. The business of communicating is the most basic tool employed by a teacher in his profession, and better ability on this area gives him the confidence to impart his expertise on the lesson to his students. Thus, TEIs need to reconsider their admission policies with great emphasis given on communication ability. The student teaching supervisors and educators, therefore, may add specific courses in the curriculum to address the poor communication ability of the student teachers. The Teacher Education curriculum may be modified to address the incompetencies of the student teachers and the upcoming needs and changes in elementary and high school curricula. As Tan, Polong, Collantes, and Torres (2020) surmised, there is a need for language educators to strengthen the teaching of communication skills.

TEIs may orient the cooperating school's administrator on their roles and responsibilities as well as requirements that can only be retrieved from the student teachers. School administrators may also refrain from seeking financial donations or contributions from student teachers. Likewise, DepEd may consider providing instructional materials to student teachers to help them carry out the task assigned to them without bothering themselves making and spending materials that are too expensive. TEIs may strengthen the curriculum specifically the course intended/responsible in developing student teachers ability and skill in the preparation and use of instructional materials. Finally, there is a need for Student Teaching supervisors to be evaluated yearly to ensure that the experiences/activities they provide are still viable and contribute to the different dimensions of being a good teacher of the student teachers.

\section{Disclosure statement}

No potential conflict of interest was reported by the author.

\section{Acknowledgments}

The author would like to extend her sincere appreciation and gratitude to the Indonesian Research Journal in Education (IRJE) for serving as platform to the researcher and providing an avenue as well as opportunity to publish her scholarly works. 


\section{IRJE | Indonesian Research Journal in Education | | Vol. 5 | No. 1|June | Year 2021|}

\section{References}

Adanza, E. (2015). Research methods: Principles and applications. Rex Bookstore, Inc.

Ambrosetti, A. (2014). Are you ready to be a mentor? Preparing teachers for mentoring pre-service teachers. Australian Journal of Teacher Education, 39(6), 30-42

Basturk, S. (2009). Investigating teaching practice course according to student teachers' opinions. Elementary Education Online, 8, 439-456.

Berchuke, A.L., Thomas, E. B., \& James, D. (2013). Teaching Practice for the $21^{\text {st }}$ Century: Challenges and Prospects for Teacher Education in the North-West Province, South Africa. J SocSci., 37(3),279-291.

Bustos, A.S., \& Espritu, S.C. (1996). Psychological, anthropological and sociological foundations of education. Katha Publishing Co.,Inc.

Cohen, I, Manion, L., \& Morrison, K. (1996). A guide to teaching practice. London: Routledge Falmer.

de la Rama, J.M., Sabasales, M., Antonio, A., Ricohermoso, C., Torres, J.M, Devanadera, A., Tulio, C., \& Alieto, E. (2020). Virtual teaching as the 'new norm': Analyzing science teachers' attitude toward online teaching, technological competence and access. International Journal of Advanced Science and Technology, 29(7), 2705-12715.

Ganal, N., Andaya, O., \& Guiab, M. (2016). Problems and difficulties encountered by student teachers of Philippine Normal University Isabela Campus. International Journal of Science and Engineering, 1(9) http://ephjournal.com/EPH-Pdf

Gokce, E \& Demirhan, C. (2005). Teacher candidates and supervising teacher's opinion about activities of teaching practice in elementary schools, Ankara University, Journal of Educational Sciences, 1, 43-71.

Guyton, E., \& McIntyre, D.J. (1990). Student teaching and school experiences. In W.R. Houston (ed). Handbook of research on teacher education (pp. 329-348). New York: Macmillan.

Haigh, M., Pinder, H., \& McDonald, L. (2006). Practicums' contribution to students' learning to teach. British Educational Research Association Annual Conference. https://www.coursehero.com/file/29094020/160597doc/

Koross, R. (2010). The student teachers' experiences during teaching practice and its impact on their perception of the teaching profession. IRA-International Journal of Education \& Multidisciplinary Studies, 5(2), 76-85.

Laruan, M. J. (2006). Problems of student teachers. The Modern Teacher, LV(1).

Morrison, K., \& Werf, G. (2012). Educational research and evaluation: An international journal on theory and practice. Educational Research and Evaluation, 18(5), 2099-2401.

Okubia, E., Augustine, O., \& Osagie, R. (2013). An analysis of perceived challenges faced by student-teachers during practice teaching exercise. Journal of Education and Practice, 4(11), 7-12.

Prastomo, Y. A., \& Listyani. (2016). Problems encountered by student-teachers in two junior high schools in central java. Humanizing Language Teaching By Pilgrims, 22(4), 21-25.

Perry, R. (2013). Teaching practice for early childhood: A guide for students. Rutledge. 


\section{IRJE | Indonesian Research Journal in Education | | Vol. 5 | No. 1|June | Year 2021|}

Rakasiwi, R. (2013). Five pre-service teachers' interaction strategies dealing with passive junior high school students in Englich class: $A$ study at SMPN 1 Banyubiru (Doctoal Dissertation, Program Studi Pendidikan Bahasa Inggris FBS-UKSW.

Robles, R.M.V., \& Torres, J.M. (2020). Filipino ESL teachers' attitudes, practices and challenges in using peer correction strategy in teaching writing. Ciencia (HEALS), 1(1), 1-26).

Samson, P. (2007). Problems and difficulties encountered by student teachers of Philippine Normal University, Alicia, Isabela. https://www.semanticscholar.org/paper/PROBLEMS-AND-DIFFICULTIES-EN COUNTERED-BY-STUDENT-OF-Ganal-Andaya/6d9ae426e37254fe413fc183bc4 09a9798506c82.

Saricoban, A. (2010). Problems encountered by student-teachers during their practicum studies. Procedia Social and behavioural Sciences, 2, 707 -711.

Soslau, E., \& Raths, J. (2017). Problems in student teaching. The Journal of Teaching and Learning, 11(1), 20-28.

Tan, R. K., Polong, R.B., Collantes, L.M., \& Torres, J.M. (2020). Influence of small group discussion on the English oral communication self-efficacy of Filipino ESL learners in Central Luzon. TESOL International Journal, 15(1).

Tok, S. (2010). The problems of teacher candidates about teaching skills during teaching practice. Procedia Social and Behavioral Sciences, 2, 4142-4136.

Torres, J. M., Pariña, J. M., Collantes, L. M., Tan, \& Richard, K. (2020). Humor styles and perceptions of college students in Central Luzon. The Asian ESP Journal, 16(2.1), 196-209.

Torres, J. M., \& Alieto, E.O. (2019b). English learning motivation and self-efficacy of Filipino senior high school students. The Asian EFL Journal, 22(1), 51-72.

Ulla, M. B. (2016). Pre-service Teacher Training Programs in the Philippines: The Student-teachers Practicum Teaching Experience. The Asian EFL Journal, 1(3), 235-250.

\section{Biographical notes}

Dr. LEILA M. COLLANTES, a Professor VI, is a faculty of the Secondary Education Department, College of Education, Central Luzon State University, Philippines. She handles several courses related to education, both in the undergraduate and graduate programs. She has been in the academe for more than 23 years. In those years, she served as chair and member of the different examining committees, adviser, and member advisory committee of graduate students taking up their thesis and dissertation in the graduate program; leilacollantes@,clsu.edu.ph 